\title{
Production of Lymphotoxin and Tumor Necrosis Factor by Human Neonatal Mononuclear Cells
}

\author{
B. KEITH ENGLISH, SANDRA K. BURCHETT, JOEY D. ENGLISH, ARTHUR J. AMMANN, \\ DIANE W. WARA, AND CHRISTOPHER B. WILSON
}

\begin{abstract}
Department of Pediatrics, University of Washington and the Division of Infectious Disease, Children's Hospital and Medical Center, Seattle, Washington [B.K.E., S.K.B., J.D.E., C.B.W.], Genentech, Inc. [A.J.A.], South San Francisco, and Department of Pediatrics, University of California [D.W.W.], San Francisco, California
\end{abstract}

\begin{abstract}
Lymphotoxin (LT) and tumor necrosis factor (TNF) are cytokines with many common biologic effects including antiviral activity and induction of fever and the acute phase response; despite common effects, they are molecularly distinct. Because neonates are unduly susceptible to viral infection and frequently fail to mount a febrile response to infection, we hypothesized that neonatal cells would produce less LT and TNF than adult cells. We analyzed LT and TNF production by blood mononuclear cells and purified $T$ cells using Northern blot analysis to detect specific messenger ribonucleic acid and specific assays to detect $\mathrm{LT}$ and TNF protein in culture supernatants. Compared to LT, TNF messenger ribonucleic acid and protein were produced more rapidly both by total mononuclear cells and by $T$ cells in response to mitogen stimulation. Although there was intersubject variability, adult and neonatal mononuclear cells and T cells $(n=6)$ produced similar amounts of LT and TNF messenger ribonucleic acid and protein with similar kinetics. In experiments with phytohemagglutinin-stimulated mononuclear cells from ten additional subjects, supernatant LT was somewhat greater in neonatal cultures (neonatal $=62.8 \pm$ 60.5 , adult $=13.2 \pm 10.7$ units $/ \mathrm{ml}, p<0.05)$, and TNF was somewhat greater in adult cultures (neonatal $=708 \pm$ 429 , adult $=1987 \pm 392 \mathrm{pg} / \mathrm{ml}, p<0.01$ ) at $24 \mathrm{~h}$; results at $48 \mathrm{~h}$ and $72 \mathrm{~h}$ were similar. Thus, neonatal MC produced as much or more LT than did adult MC. Although the decreased production of TNF by neonatal MC was statistically significant, these cells did produce substantial amounts of this cytokine. Because the reduction in TNF production by neonatal $\mathrm{MC}$ in response to nonspecific stimuli was modest, it is unlikely to be the principal mechanism but may contribute to the diminished febrile response and increased susceptibility to infection of the human neonate. (Pediatr Res 24:717-722, 1988)
\end{abstract}

Abbreviations

LT, lymphotoxin

rLT, recombinant lymphotoxin

TNF, tumor necrosis factor

rTNF, recombinant tumor necrosis factor

IFN- $\gamma$, interferon-gamma

IL-2, interleukin-2

mRNA, messenger ribonucleic acid

MC, mononuclear cells

Received June 2, 1988; accepted August 10, 1988.

Correspondence B. Keith English, M.D., Division of Infectious Diseases, Children's Hospital and Medical Center, P.O. Box C5371, Seattle, WA 98105.

Supported in part by grants from the National Institutes of Health and United Cerebral Palsy.

\author{
HBSS, Hanks' balanced salt solution \\ LPS, lipopolysaccharide \\ PMA, phorbol myristate acetate \\ PHA, phytohemagglutinin \\ FCS, fetal calf serum \\ Con A, concanavalin A \\ OPD, ortho-phenylenediamine
}

LT and TNF are cytokines with minimal molecular homology but multiple common biologic activities, including antitumor and antiviral effects and mediation of fever and the acute phase response to infection $(1-3)$. These effects are potentiated by (IFN$\gamma$. TNF, also called TNF- $\alpha$, is principally a monocyte/macrophage product (4-6) but is also produced by natural killer cells (7-9) and $T$ cells (9). LT, also called TNF- $\beta$, is primarily a product of T lymphocytes $(10,11)$; though the cDNA for LT was initially cloned from a B-cell lymphoblastoid cell line (11), it is not produced by purified B cells (12), monocytes (10), or natural killer cells (8). We and others have previously reported diminished production of IFN- $\gamma$ by mitogen-stimulated neonatal T cells compared to adult T cells (13-17), and we have shown that this is associated with diminished production of IFN- $\gamma$ mRNA but normal production of IL2 and IL2 receptor proteins and their cognate mRNA $(13,14)$. A previous study reported decreased LT activity in the supernatants of mitogen-stimulated neonatal $\mathrm{MC}$ as compared with adult peripheral blood $\mathrm{MC}$ (18). However, the assay used in that study would have measured LT, TNF- $\alpha$, and perhaps other lymphokines, including IFN- $\gamma$. TNF and LT have been recently cloned and characterized $(6,10)$, allowing a more specific analysis of their production.

In this study, we examined the hypothesis that neonatal MC and $T$ cells produce less $L T$ and TNF after mitogenic stimulation than do adult $\mathrm{MC}$ and $\mathrm{T}$ cells. We studied the accumulation of LT and TNF in supernatants of stimulated adult and neonatal cord blood $\mathrm{MC}$ and $\mathrm{T}$ cell preparations and also measured the accumulation of the specific mRNA for LT, TNF, and IFN- $\gamma$ by Northern blot analysis.

\section{MATERIALS AND METHODS}

Reagents. HBSS, L-glutamine, penicillin, and streptomycin were obtained from Gibco (Grand Island Biological Co., Grand Island, NY). RPMI 1640 containing 25 mM HEPES buffer was obtained from Whittaker MA Bioproducts (Walkersville, MD) or Cellgro (Dulles International Airport, Washington, DC) and contained $<0.3$ EU LPS/ml by Limulus amebocyte lysate assay (Pyrotell Associates of Cape Cod, Inc., Woods Hole, MA). FicollHypaque and Con A were obtained from Pharmacia Fine Chem- 
icals (Piscataway, NJ). PMA was obtained from Sigma Chemical Co. (St. Louis, MO). Actinomycin D was obtained from Calbiochem (La Jolla, CA). L-929 fibroblast cells, mycoplasma-free by the Kaplan method (19), were supplied by Dr. Gale Granger (University of California, Irvine, CA). PHA-P was obtained from Burroughs-Wellcome (Research Triangle Park, NC) and PHA$\mathrm{M}$ was obtained from Difco (Detroit, MI).

Human recombinant LT (spec. act. $1.2 \times 10^{8} \mathrm{U} / \mathrm{mg}$ ), human recombinant TNF (spec. act. $5 \times 10^{7} \mathrm{U} / \mathrm{mg}$ ), rabbit polyclonal anti-LT antibody (spec. act. $2.9 \times 10^{7}$ neutralizing $U / \mathrm{ml}$ ), rabbit polyclonal anti-TNF antibody $\left(5.95 \times 10^{5}\right.$ neutralizing $\left.\mathrm{U} / \mathrm{ml}\right)$, mouse monoclonal anti-TNF antibody (specific activity $6 \times 10^{6}$ neutralizing $\mathrm{U} / \mathrm{mg}$ ), and horseradish peroxidase conjugated mouse monoclonal anti-TNF antibody were supplied by Genentech, Inc. (South San Francisco, CA).

Cell preparations. MC were isolated from peripheral blood of healthy adult donors or umbilical cord blood of healthy term neonates by Ficoll-Hypaque density gradient centrifugation as previously described (20), washed twice in HBSS, resuspended in RPMI 1640 containing $2 \mathrm{mM}$ L-glutamine, $50 \mathrm{U} / \mathrm{ml}$ penicillin $\mathrm{G}, 50 \mu \mathrm{g} / \mathrm{ml}$ streptomycin, and $5 \%$ human $\mathrm{AB}$ serum (medium), and counted. Purified T cells were prepared by treatment of MC with $\mathrm{T}$ cell Lymphokwik as specified by the manufacturer (One Lambda, Los Angeles, CA). The compositions of the MC and T cell preparations were assessed by indirect immunofluorescence using $\mathrm{mAbs}$ recognizing the indicated antigens: 9.6-CD2 ( $\mathrm{T}$ and NK cells); 64.1-CD3 (T cells); 2H7-Bp32 (B cells); 5F1-CDW14 (monocytes); 1G10-CDW15 (granulocytes); M21-IgG1 murine myeloma protein (negative control), and Fcl-CD16 (NK cells). 9.6, 64.1, and $2 \mathrm{H} 7$ were obtained from Genetic Systems (Seattle, WA); 5F1 and 1 G10 were provided by Dr. I. Bernstein (Fred Hutchinson Cancer Research Center, Seattle, WA). Fcl was provided by E. Clark (University of Washington, Seattle, WA). M21 was purchased from Litton Bionetics (Kensington, MD). $\mathrm{MC}$ and T cell preparations were $>95 \%$ viable by the trypan blue exclusion method. T cell preparations were $>95 \%$ positive with $9.6,>85 \%$ positive with 64.1 , and $<1 \%$ positive with $\mathrm{M} 21$, $2 \mathrm{H} 7,5 \mathrm{~F} 1$, and $1 \mathrm{G} 10$. In the $\mathrm{T}$ cell preparations, $8-20 \%$ of cells were positive with $\mathrm{Fc} 1$.

Induction and assay of lymphokines. For the studies in which the kinetics of TNF and LT protein and mRNA accumulation were evaluated in parallel, blood MC and T cells were cultured in conical $15-\mathrm{ml}$ polypropylene tubes at $5 \times 10^{6} / \mathrm{ml}$ and stimulated with $25 \mu \mathrm{g} / \mathrm{ml}$ Con A with or without $50 \mathrm{ng} / \mathrm{ml}$ PMA. For the other studies, blood MC were cultured at $1 \times 10^{6} / \mathrm{ml}$ in microtiter wells (because fewer cells were required) and stimulated with PHA-P $(5 \mu \mathrm{g} / \mathrm{ml})$, PHA-M $(1: 40)$ or PMA $(10 \mathrm{ng} / \mathrm{ml})$. After the indicated incubation time, supernatants were collected, frozen at $-70^{\circ} \mathrm{C}$, and later assayed for LT and TNF.

TNF was assayed by a capture ELISA technique, using polyclonal rabbit anti-rTNF as coating antibody and murine monoclonal anti-rTNF conjugated to horseradish peroxidase as the second antibody. OPD was used as the substrate, and the reaction was stopped with $4.5 \mathrm{~N} \mathrm{H}_{2} \mathrm{SO}_{4}$. Absorbance at $492 \mathrm{~nm}(405 \mathrm{~nm}$ reference beam) was determined on a microplate reader. rTNF was used as a standard in each assay.

LT activity was determined by a modification of the assay described in Aggarwal et al. (4) using Actinomycin-D $(1 \mu \mathrm{g} / \mathrm{ml})-$ treated mouse L-929 fibroblasts. Appropriate serial dilutions of each supernatant were assayed for LT in parallel after preincubation for $1 \mathrm{~h}$ with 5 neutralizing units of anti-TNF mAb with or without 10 neutralizing units of anti-LT polyclonal antibody. After incubation at $37^{\circ} \mathrm{C}$ for $18 \mathrm{~h}$, samples were decanted, monolayers were washed twice with phosphate-buffered saline, and residual cells were stained with crystal violet, washed, and dried. The crystal violet was eluted, and the optical density of the eluate was determined at $550 \mathrm{~nm}(405 \mathrm{~nm}$ reference beam). Optical density of L-929 cells incubated with medium alone represented $0 \%$ lysis, and cells treated with $3 \mathrm{M}$ guanidine hydrochloride $100 \%$ lysis. One unit LT or TNF activity is that producing $50 \%$ lysis. LT activity was defined as that activity not neutralized by preincubation with the anti-TNF antibody; more than $90 \%$ of total lytic activity was neutralized by preincubation with a combination of the anti-TNF and anti-LT antibodies. rTNF and rLT were run as standards in each assay, and were completely neutralized by anti-TNF $\mathrm{mAb}$ and anti-LT polyclonal $\mathrm{Ab}$, respectively.

$R N A$ isolation and Northern blot analysis. Total cellular RNA was isolated from $\mathrm{MC}$ or T cells by the guanidinium isothiocyanate/cesium chloride method and quantitated spectrophotometrically as previously described (14). Integrity of the RNA was confirmed by electrophoresis of $1 \mu \mathrm{g}$ in $1 \%$ agarose gels and staining with ethidium bromide. For blots, $5 \mu \mathrm{g}$ RNA was electrophoresed in $2.2 \mathrm{M}$ formaldehyde- $1 \%$ agarose gels, transferred to Nytran (Schleicher \& Schuell, Keene, NH), and baked at $80^{\circ} \mathrm{C}$ for $90 \mathrm{~min}$ as described (21). Blots were hybridized with ${ }^{32} \mathrm{P}$-labeled RNA probes transcribed from the following subclones in pGEM vectors (Promega Biotec, Madison, WI): LT, the 940 bp EcoRI cDNA fragment (11); TNF, the 800 bp EcoRI cDNA fragment (6); and IFN- $\gamma$, nucleotides $266-860$ of clone 52 (22). These cDNA were originally provided by P. Gray (Genentech, Inc.). After hybridization, blots were washed at $63^{\circ} \mathrm{C}$ with $6 \times$ SSC, $0.1 \%$ SDS for 30 minutes then with $0.1 \times$ SSC, $0.1 \%$ sodium dodecyl sulfate for $30 \mathrm{~min}$, then autoradiographed at $-80^{\circ} \mathrm{C}$. In some cases, previously probed Nytran filters were stripped by boiling in $20 \mathrm{mM}$ Tris pH 8.5, 2 mM EDTA, $0.1 \%$ sodium dodecyl sulfate for $15 \mathrm{~min}$, dried, and then reprobed.

Statistics. Data are expressed as mean \pm one SD. Statistical analysis was performed by a two-tailed Student's $t$ test, and comparison groups were considered significantly different if $p<$ 0.05 .

\section{RESULTS}

Secretion of $L T$ and TNF by blood MC and T cells. We studied the kinetics of secretion of LT and TNF by adult and neonatal (cord) MC and T cell preparations after stimulation with Con A (MC) or Con A plus PMA (MC and T cells). Results from four representative experiments of six are shown in Table 1. LT activity was undetectable in unstimulated adult and neonatal $\mathrm{MC}$ and $\mathrm{T}$ cell supernatants. After stimulation, $\mathrm{LT}$ was detectable at $4-8 \mathrm{~h}$ and continued to increase thereafter, peaking at 24-48 h. TNF was undetectable or present in very small amounts in unstimulated adult and neonatal $\mathrm{MC}$ and $\mathrm{T}$ cell supernatants, rose rapidly after stimulation, and usually peaked by 16-24 h. In these representative experiments, there was considerable subject-to-subject variation for both adult and neonatal cell preparations, but, overall, adult and neonatal $\mathrm{MC}$ and $\mathrm{T}$ cells secreted similar amounts of LT and TNF with similar kinetics.

Because of the variability noted in the kinetic experiments, we also studied the secretion of LT and TNF by 10 adult and neonatal MC preparations after stimulation with either PHA or PMA (Table 2). With PHA as the stimulus, neonatal MC secreted approximately twice as much LT as adult MC, but the difference was significant only at $24 \mathrm{~h}$. PMA alone was a poor stimulus for LT production. In contrast, with PHA as the stimulus, adult MC secreted approximately twice as much TNF as neonatal MC, and the difference was significant at 24,48 , and $72 \mathrm{~h}$. With PMA as the stimulus, adult MC also produced more TNF than neonatal $\mathrm{MC}$, but this was significant only at $24 \mathrm{~h}$. In these experiments, LT secretion was greatest at $72 \mathrm{~h}$, whereas TNF secretion was maximal at $24-48 \mathrm{~h}$.

$L T$ and TNF MRNA accumulation by blood $M C$ and $T$ cells. To analyze LT and TNF production by an independent and specific method, we examined the accumulation of specific mRNAs for LT and TNF by Northern blot analysis. Initial experiments revealed that Con A plus PMA resulted in the greatest accumulation of LT and TNF mRNA, so this combination was used to examine the kinetics of LT and TNF mRNA accumulation in adult and neonatal (cord) MC (Fig. 1). For 
Table 1. Kinetics of secretion of LT and TNF by adult and neonatal (cord) blood MC*

\begin{tabular}{|c|c|c|c|c|c|c|c|c|c|}
\hline \multicolumn{10}{|c|}{$\mathrm{LT}(\mathrm{U} / \mathrm{ml})$} \\
\hline \multirow[b]{2}{*}{ Exp. } & \multirow[b]{2}{*}{ Subject } & \multirow[b]{2}{*}{ Cell type } & \multirow[b]{2}{*}{ Stimulus } & \multicolumn{6}{|c|}{ Time after stimulation $(\mathrm{h})$} \\
\hline & & & & 0 & 4 & 8 & 16 & 24 & 48 \\
\hline \multirow[t]{2}{*}{1} & Adult 1 & $\mathrm{MC}$ & Con A & 0 & 56 & 71 & 128 & 172 & 500 \\
\hline & Neonate 1 & $\mathrm{MC}$ & Con A & 0 & 49 & 52 & 15 & 76 & 104 \\
\hline \multirow[t]{2}{*}{2} & Adult 2 & $\mathrm{MC}$ & Con A + PMA & 0 & ND & 33 & 10 & 195 & 115 \\
\hline & Neonate 2 & MC & $\operatorname{Con} \mathrm{A}+\mathrm{PMA}$ & $\mathrm{ND} \dagger$ & ND & 80 & 40 & 105 & ND \\
\hline \multirow[t]{2}{*}{3} & Adult 3 & $\mathrm{~T}$ cells & Con $\mathrm{A}+\mathrm{PMA}$ & 0 & ND & 35 & 35 & 175 & 690 \\
\hline & Neonate 3 & $\mathrm{~T}$ cells & Con $\mathrm{A}+\mathrm{PMA}$ & 0 & ND & ND & ND & 810 & 1255 \\
\hline \multirow[t]{2}{*}{4} & Adult 4 & $\mathrm{~T}$ cells & $\operatorname{Con} \mathrm{A}+\mathrm{PMA}$ & 0 & ND & 15 & ND & 705 & 1056 \\
\hline & Neonate 4 & $\mathrm{~T}$ cells & Con A + PMA & 0 & $\mathrm{ND}$ & 89 & ND & 1367 & 1330 \\
\hline \multicolumn{10}{|c|}{$\mathrm{TNF}(\mathrm{pg} / \mathrm{ml})$} \\
\hline & & & & \multicolumn{6}{|c|}{ Time after stimulation (h) } \\
\hline Exp. & Subject & Cell type & Stimulus & 0 & 4 & 8 & 16 & 24 & 48 \\
\hline \multirow[t]{2}{*}{1} & Adult 1 & $\mathrm{MC}$ & Con A & 78 & 1188 & 1300 & 1334 & 1741 & 1006 \\
\hline & Neonate 1 & $\mathrm{MC}$ & Con A & 0 & 914 & 1447 & 957 & 862 & 406 \\
\hline \multirow[t]{2}{*}{2} & Adult 2 & $\mathrm{MC}$ & Con A + PMA & ND & ND & 5098 & 10690 & 9850 & ND \\
\hline & Neonate 2 & MC & Con A + PMA & ND & ND & 1353 & 2869 & 2973 & ND \\
\hline \multirow[t]{2}{*}{3} & Adult 3 & $\mathrm{~T}$ cells & Con A + PMA & 0 & 2082 & 7076 & 9473 & 10726 & 10593 \\
\hline & Neonate 3 & $\mathrm{~T}$ cells & Con A + PMA & 0 & ND & ND & 8248 & 13650 & 13885 \\
\hline \multirow[t]{2}{*}{4} & Adult 4 & $\mathrm{~T}$ cells & Con A + PMA & 0 & ND & 7605 & ND & 18180 & 16230 \\
\hline & Neonate 4 & $\mathrm{~T}$ cells & Con A + PMA & 0 & ND & 4036 & ND & 11812 & 7733 \\
\hline
\end{tabular}

* Cells were cultured at $5 \times 10^{6} / \mathrm{ml}$ in $15-\mathrm{ml}$ polypropylene tubes and stimulated with Con $\mathrm{A}(25 \mu \mathrm{g} / \mathrm{ml})$ with or without PMA (50 ng/ml) for the indicated interval. Supernatants were assayed as described in "Materials and Methods."

$\uparrow \mathrm{ND}$, not determined.

Table 2. Secretion of LT and TNF by adult and neonatal (cord) blood MC*

\begin{tabular}{llccc}
\hline & & \multicolumn{3}{c}{$\begin{array}{c}\text { LT (U/ml) } \\
\text { Time after stimulus (h) }\end{array}$} \\
\cline { 3 - 5 } Subject & Stimulus & 24 & 48 & 72 \\
\hline Adult & PHA & $13.2 \pm 10.7 \dagger$ & $168.3 \pm 154.4$ & $238.2 \pm 183.4$ \\
Neonatal & PHA & $62.8 \pm 60.5 \dagger$ & $283.6 \pm 279.6$ & $433.6 \pm 706.5$ \\
Adult & PMA & $10.0 \pm 4.8 \dagger$ & $33.4 \pm 25.1$ & $41.8 \pm 39.2 \dagger$ \\
Neonatal & PMA & $5.2 \pm 3.1 \dagger$ & $51.9 \pm 143.1$ & $7.2 \pm 5.1 \dagger$ \\
& & & TNF (pg/ml) & 72 \\
\hline & & & Time after stimulus (h) & \\
& Stimulus & 24 & 48 & $1186.9 \pm 956.9 \dagger$ \\
Adult & PHA & $1986.6 \pm 391.6 \$$ & $2160.2 \pm 519.3 \dagger$ & $598.1 \pm 390.1 \dagger$ \\
Neonate & PHA & $708.3 \pm 428.7 \dagger$ & $995.6 \pm 838.7 \dagger$ & $2240.7 \pm 2217.9$ \\
Adult & PMA & $3227.2 \pm 1938.0 \dagger$ & $1797.6 \pm 1313.3$ & $888.4 \pm 348.2$ \\
Neonate & PMA & $774.1 \pm 897.1 \dagger$ & $1070.7 \pm 637.9$ & \\
\hline
\end{tabular}

* Cells were cultured at $1 \times 10^{6} / \mathrm{ml}$ in microtiter wells and stimulated with PHA-P $(5 \mu \mathrm{g} / \mathrm{ml})$ or PMA $(10 \mathrm{ng} / \mathrm{ml})$ for the indicated interval. Results are means \pm SD of 10 experiments each. Supernatants were assayed as described in "Materials and Methods."

$\dagger p<0.05$.

$\ddagger p<0.01$.

comparison, accumulation of IFN- $\gamma$ mRNA was studied in parallel.

LT mRNA was not detectable in unstimulated adult and neonatal MC. After stimulation, LT mRNA was detectable by 4 $\mathrm{h}$, peaked by $8-24 \mathrm{~h}$, and remained elevated at $48 \mathrm{~h}$. TNF mRNA was just detectable in unstimulated adult and neonatal $\mathrm{MC}$, rose rapidly after stimulation, peaked by $8 \mathrm{~h}$, and returned to baseline levels by $24-48 \mathrm{~h}$. In this experiment, adult $\mathrm{MC}$ contained slightly more LT and TNF mRNA than neonatal MC, whereas in other experiments neonatal MC contained somewhat more LT and TNF mRNA than adult MC (not shown). In contrast, IFN- $\gamma$ accumulation was dramatically reduced in neonatal MC in all experiments, as previously reported (14).

Results of Northern blot analyses of $T$ cell preparations paralleled those of MC (Fig. 2). Neonatal T cells produced as much or more LT and TNF mRNA as did adult T cells. IFN- $\gamma$ mRNA accumulation was greatly diminished in neonatal $T$ cell preparations as compared with adult $\mathrm{T}$ cells.

\section{DISCUSSION}

Our data indicate that neonatal blood $\mathrm{MC}$ and $\mathrm{T}$ cells produce and secrete both LT and TNF in response to mitogens. It is likely that some of the TNF produced by blood MC under our conditions was derived from monocytes. However, because monocytes secrete less TNF in response to Con A or PHA than do lymphocytes (9), do not secrete $\operatorname{LT}(9,12,23)$, and comprised less than $20 \%$ of the total cells in MC preparations, most of the TNF and LT was probably derived from T cells and NK cells. This is supported by experiments with $\mathrm{T}$ cell enriched, monocyte-de- 

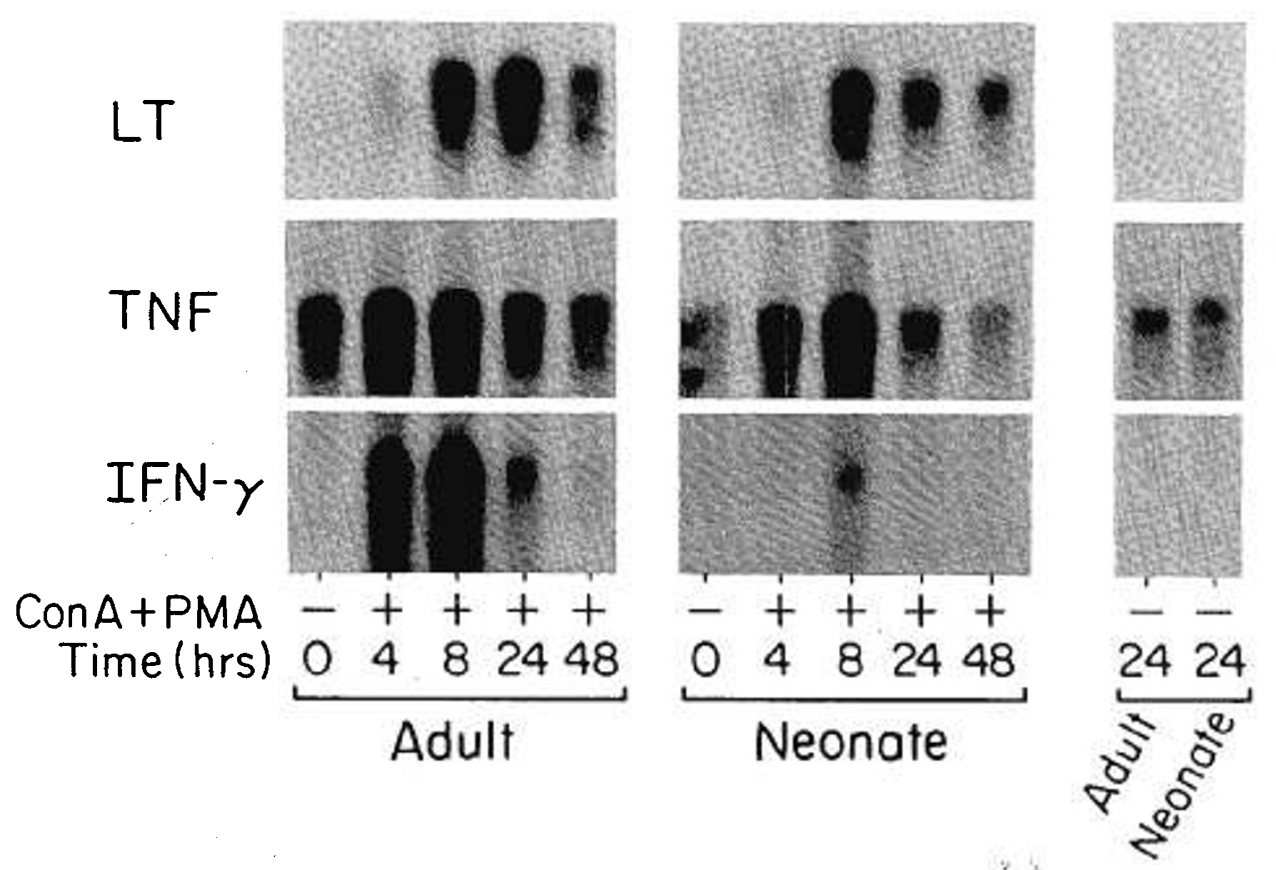

Fig. 1. Northern blot analysis of blood mononuclear cell (MC) RNA. Cells were cultured at $5 \times 10^{6} / \mathrm{ml}$, and stimulated with Con A plus PMA as described in the Materials and Methods. RNA was isolated from MC at the indicated times. In each lane, $5 \mu \mathrm{g}$ of total RNA was electrophoresed.

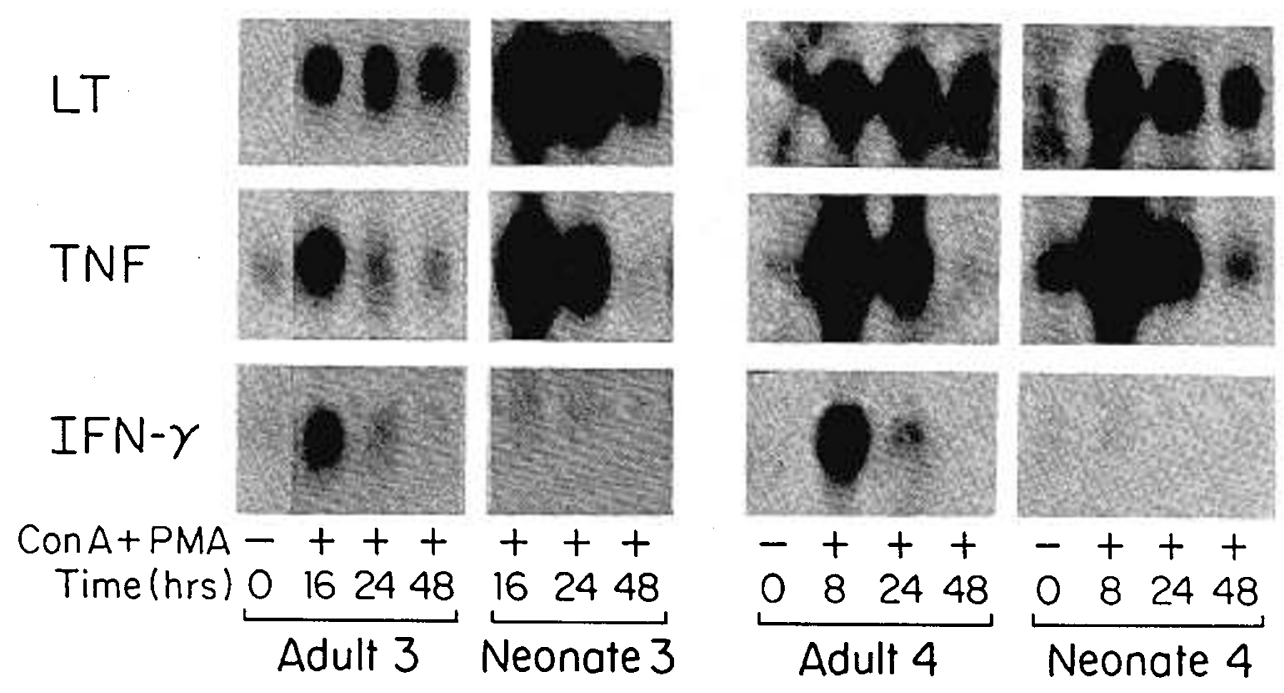

Fig. 2. Northern blot analysis of T cell preparations. T cells were cultured at $5 \times 10^{6} / \mathrm{ml}$ and stimulated with Con A plus PMA as described in the "Materials and Methods." RNA was isolated from $T$ cells at the indicated times. In each lane, $5 \mu \mathrm{g}$ of total RNA was electrophoresed.

pleted $(<1 \%)$ preparations, which secreted at least as much TNF and $\mathrm{LT}$ and contained as much or more of their cognate mRNAs as did MC preparations under our conditions. In other studies, we have found that blood monocytes from adults and neonates secrete comparable amounts of TNF (24). Our T cell-enriched preparations were $>95 \% \mathrm{CD} 2+$; of these $85-90 \%$ were $\mathrm{CD} 3+\mathrm{T}$ cells and $8-20 \%$ were CD $16+\mathrm{NK}$ cells. However, lectins are poor activators of NK cells (25), and NK cells stimulated with PHA, phorbol ester, or both secrete much less TNF than do T cells or MC (9) and do not secrete LT $(8,9)$. We have found that adult $\mathrm{T}$ cells depleted of NK cells by monoclonal anti-CD16 antibody plus complement contain as much or more TNF and LT mRNA in response to Con A plus PMA as T cells or whole MC containing $\sim 10 \%$ NK cells (data not shown). Thus, it is likely that our results largely reflect production of LT and TNF by $\mathrm{T}$ cells.
Although there was substantial variability, we found that neonatal MC produced approximately twice as much LT and approximately $1 / 2$ as much TNF as adult MC. In contrast to this modest 2-fold lower TNF production. IFN- $\gamma$ production by neonatal $\mathrm{MC}$ is less than $1 / 10$ that of adult $\mathrm{MC}$ after mitogen stimulation (13). Although the number of experiments was more limited, results with $T$ cells were similar except that TNF production by neonatal and adult $\mathrm{T}$ cells was comparable. Northern blot analyses also indicated that neonatal and adult $\mathrm{MC}$ and $\mathrm{T}$ cells produced similar amounts of LT and TNF mRNA, which contrasted with the markedly lower amount of IFN- $\gamma$ mRNA. TNF protein and mRNA accumulated more rapidly than did LT protein and mRNA in both adult and neonatal cells.

These results differ somewhat from those of Eife et al. (18), who found that neonatal MC produced $\sim 40 \%$ as much lymphotoxin as adult MC. These workers assayed PHA stimulated MC 
supernatants for activity that inhibited ${ }^{3} \mathrm{H}$-thymidine incorporation by a human hepatoma cell line; they referred to this activity as lymphotoxin. It is difficult to be certain which cytokines were measured by this assay, because these studies were performed before specific reagents were available to distinguish between these molecules. It is likely that the combined activity of $\mathrm{LT}$, TNF, and IFN- $\gamma$ [because human IFN- $\gamma$ potentiates the cytotoxic effects of LT and TNF on human but not mouse cells (26)] and perhaps other cytokines were measured in their assay. We used a specific enzyme immunoassay to detect TNF and specific neutralization to determine LT bioactivity. We confirmed these results by measuring the accumulation of the specific mRNAs for LT and TNF. Thus, we are confident that the results obtained are specific for these molecules. It is possible that the diminished lytic activity of neonatal MC supernatants reported by Eife $e t$ al. (18) reflected the slightly lower production of TNF, the greatly diminished production of IFN- $\gamma$, or both. Other technical differences also may have contributed to the differences in findings.

TNF and LT have pleiotropic biologic effects in addition to their cytotoxic effects on tumor cells. These include the induction of acute phase protein synthesis (27) and fever (28), enhancement of granulocyte function (29-31) and myeloid differentiation (32), synergistic enhancement with IFN- $\gamma$ of HLA class II expression (33) and of viral growth inhibition $(34,35)$. Compared to adults, neonates have deficiencies or immature responses of certain host defense mechanisms, among which are a diminished febrile response, abnormal granulocyte chemotaxis and limited marrow myeloid reserves with resultant decreased recruitment of granulocytes at sites of inflammation, and decreased expression of HLA class II molecules (reviewed in Refs. 36, 37). It is possible that the modest decrease in TNF production by neonatal MC after nonspecific stimulation contributes to these deficiencies. Other work in our laboratory has shown that freshly isolated neonatal and adult monocytes secrete similar amounts of TNF after stimulation; however, monocyte-derived and tissue macrophages from neonates secrete less TNF than adult macrophages, and TNF secretion by neonatal macrophages is not enhanced by the addition of IFN- $\gamma$ as it is in adult macrophages (24). Taken together, these results suggest that the diminished production of TNF by neonatal $T$ cells and macrophages may play a role in the decreased febrile response and the increased susceptibility to infection of the human neonate. Nevertheless, because TNF and LT share a common receptor and have nearly identical biologic activities $(1,3,11,29-31,38-43)$, with rare exceptions $(44,45)$, the greater production of $\mathrm{LT}$ may in part counterbalance the decrease in TNF production under conditions in which the production of both cytokines is coordinately induced. Studies to assess the production of these cytokines in vivo will be required to address this possibility.

\section{REFERENCES}

1. Dinarello CA, Mier JW 1987 Lymphokines. N Engl J Med 317:940-945

2. Beutler B, Cerami A 1987 Cachectin: More than a tumor necrosis factor. $\mathrm{N}$ Engl J Med 316:379-385

3, Old LJ 1987 Polypeptide mediator network. Nature 326:330-331

4. Aggarwal BB, Kohr WJ, Hass PE, Moffat B, Spencer SA, Henzel WJ, Bringman TS, Nedwin GE, Goeddel DV, Harkins RN 1985 Human tumor necrosis factor: production, purification and characterization. J Biol Chem 260:23452354

5. Beutler B, Greenwald D, Hulmes JD, Chang M. Pan Y-CE, Mathison J, Ulevitch. R, Cerami A 1985 Identity of tumor necrosis factor and the macrophage-secreted factor cachectin. Nature 316:552-558

6. Pennica D, Nedwin GE, Hayflick JS, Seeburg PH, Derynck R, Palladino MA, Kohr WJ, Aggarwal BB, GoeddeI DV 1984 Human tumour necrosis factor: precursor structure, expression and homology to lymphotoxin. Nature 312:724-729

7. Degliantoni G, Murphy M, Kobayashi M, Francis MK, Perussia B, Trinchieri G 1985 Natural killer (NK) cell-derived hematopoietic colony-inhibiting activity and NK cytotoxic factor. J Exp Med 162:1512-1530

8. Peters PM, Ortaldo JR, Shalaby R, Svedersky LP, Nedwin GE, Bringman TS, Hass PE, Aggarwal BB, Herberman RB, Goeddel DV, Palladino MA Jr 1986 Natural killer-sensitive targets stimulate production of TNF- $\alpha$ but not TNF- $\beta$ (lymphotoxin) by highly purified human peripheral blood large granular lymphocytes. J Immunol 137:2592-2598

9. Cuturi MC, Murphy M, Costa-Giomi MP, Weinmann R, Perussia B, Trinchieri G 1987 Independent regulation of tumor necrosis factor and lymphotoxin production by human peripheral blood lymphocytes. J Exp Med 165:15811594

10. Aggarwal BB, Henzel WJ, Moffat B, Kohr WJ, Harkins RN 1985 Primary structure of human lymphotoxin derived from 1788 . lymphoblastoid cell line. J Biol Chem 260:2334-2344

11. Gray PW, Aggarwal BB, Benton CV, Bringman TS, Henzel WJ, Jarrett JA, Leung DW, Moffat B, Ng P, Svedersky LP, Palladino MA, Nedwin GE 1984 Cloning and expression of cDNA for human lymphotoxin, a lymphokine with tumour necrosis activity. Nature 312:721-724

12. Ruddle NH 1985 Lymphotoxin redux. Immunology Today $6: 156-159$

13. Wilson CB, Westall J, Johnston L, Lewis DV, Dower SK, Alpert AR 1986 Decreased production of interferon-gamma by human neonatal cells. J Clin Invest 77:860-867

14. Lewis DB, Larsen A, Wilson CB 1986 Reduced interferon-gamma mRNA levels in human neonates. J Exp Med 163:1018-1023

15. Bryson YJ, Winter HS, Gard SE, Fischer TJ, Stiehm ES 1980 Deficiency of immune interferon production by leukocytes of normal newborns. Cell Immunol 55:191-200

16. Wakasugi N, Virelizier J-L 1985 Defective IFN- $\gamma$ production in the human neonate. I. Dysregulation rather than intrinsic abnormality. J Immunol 134:167-171

17. Wakasugi N, Virelizier J-L, Arenzana-Seisdedos F, Rothhut B, Mencia-Huerta J-M, Russo-Marie F, and Fiers W 1985 Defective IFN- $\gamma$ production in the human neonate. II. Role of increased sensitivity to the suppressive effects of prostaglandin E. J Immunol 134:172-176

18. Eife RF, Eife G, August CS, Kuhre WL, Staehr-Johansen K 1974 Lymphotoxin production and blast cell transformation by cord blood lymphocytes: dissociated lymphocyte function in newborn infants. Cell Immunol 14:435-442

19. Kaplan DR, Henkel TJ, Braciale V, Braciale TJ 1984 Mycoplasma infection of cell cultures: thymidine incorporation of culture supernatants as a screening test. J Immunol 132:9-1

20. Wilson CB, Remington JS 1979 Effects of monocytes from human neonates on lymphocyte transformation. Clin Exp Immunol 36:511-520

21. Maniatis T, Fritsch EF, Sambrook J 1982 Extraction, purification and analysis of mRNA from eukaroytic cells. In: Molecular Cloning: A Laboratory Manual, Cold Spring Harbor Laboratory Press, Cold Spring Harbor, NY, pp 187-209

22. Gray PW, Leung DW, Pennica D, Yelverton E, Najarian R, Simonsen CC, Derynck R, Sherwood PJ, Wallace DM, Berger SL, Levinson AD, Goeddel DV 1982 Expression of human immune interferon cDNA in $E$. coli and monkey cells. Nature 295:503-508

23. Nedwin GE, Svedersky LP, Bringman TS, Palladino MA Jr, Goeddel DV 1985 Effect of interleukin 2, interferon- $\gamma$, and mitogens on the production of tumor necrosis factors $\alpha$ and $\beta$. J Immunol 135:2492-2497

24. Burchett SK, Weaver WM, Westall JA, Larsen A, Kronheim S, Wilson CB 1988 Regulation of tumor necrosis factor/cachectin and interleukin 1 secretion in human mononuclear phagocytes. J Immunol, 140:3473-3481

25. London L, Perussia B, Trinchieri G 1985 Induction of proliferation in vitro of resting human natural killer cells: Expression of surface activation antigens. J Immunol 134:718-727

26. Stone-Wolff DS, Yip YK, Kelker HC, Le J, Henriksen-Destefano D, Rubin BY, Rinderknecht E, Aggarwal BB, Vilcek J 1984 Interrelationships of human interferon-gamma with lymphotoxin and monocyte cytotoxin. J Exp Med 159:828-843

27. Perlmutter DH, Dinarello CA, Punsal PI, Colten HR 1986 Cachectin/tumor necrosis factor regulates hepatic acute-phase gene expression. J Clin Invest 78:1349

28. Dinarello CA, Cannon JG, Wolff SM, Bernheim HA, Beutler B, Cerami A, Figari IS, Palladino MA, O'Connor JV 1986 Tumor necrosis factor (cachectin) is an endogenous pyrogen and induces production of interleukin 1 . J Exp Med 163:1433-1450

29. Shalaby MR, Aggarwal BB, Rinderknecht E, Svedersky LP, Finkle BS, Palladino MA Jr 1985 Activation of human polymorphonuclear neutrophil functions by interferon- $\gamma$ and tumor necrosis factors. I Immunol 135:20692073

30. Perussia B, Kobayashi M, Rossi ME, Anegon I, Trinchieri G 1987 Immune interferon enhances functional properties of human granulocytes: Role of Fc receptors and effect of lymphotoxin, tumor necrosis factor, and granulocytemacrophage colony-stimulating factor. J Immunol 138:765-774

31. Ming WJ, Bersani L, Mantovani A 1987 Tumor necrosis factor is chemotactic for monocytes and polymorphonuclear leukocytes. J Immunol 138:14691474

32. Trinchieri G, Kobayashi M, Rosen M, Loudon R, Murphy M, Perussia B 1986 Tumor necrosis factor and lymphotoxin induce differentiation of human myeloid cell lines in synergy with immune interferon. J Exp Med 164:12061225

33. Puhol-Borrell R, Todd I, Doshi M, Bottazzo GF, Sutton R, Gray D, Adolf GR, Feldmann M 1987 HLA class II induction in human islet cells by interferon- $\gamma$ plus tumour necrosis factor or lymphotoxin. Nature 326:304306

34. Wong GHW, Goeddel DV 1986 Tumour necrosis factor $\alpha$ and $\beta$ inhibit virus replication and synergize with interferons. Nature 323:819-822 
35. Mestan J, Digel W, Mittnacht S, Hillen H, Blohm D, Moller A, Jacobsen H, Kirchner H 1986 Antiviral effects of recombinant tumor necrosis factor in vitro. Nature 323:816-819

36. Wilson CB 1986 Immunologic basis for increased susceptibility of the neonate to infection. J Pediatr 108:1-12

37. Wilson CB 1988 Developmental immunology and role of host defenses in neonatal susceptibility. In: Remington JS, Klein JO (eds), Infectious Diseases of the Fetus and Newborn (in press)

38. Kehrl JH, Miller A, Fauci AS 1987 Effect of tumor necrosis factor $\alpha$ on mitogen-activated human B cells. J Exp Med 166:786-791

39. Kehrl JH, Alvarez-Mon M, Delsing GA, Fauci AS 1987 Lymphotoxin is an important $T$ cell-derived growth factor for human B cells. Science 238:11441146

40. Pober JS, Lapierre LA, Stolpen AH, Brock TA, Springer TA, Fiers W, Bevilacqua MP, Mendrick DL, Gimbrone MA Jr 1987 Activation of cultured human endothelial cells by recombinant lymphotoxin: Comparison with tumor necrosis factor and interleukin 1 species. J Immunol 138:3319-3324
41. Thomson BM, Mundy GR, Chambers TJ 1987 Tumor necrosis factors $\alpha$ and $\beta$ induce osteoblastic cells to stimulate osteoclastic bone resorption. $\mathrm{J}$ Immunol 138:775-779

42. Stashenko P, Dewhirst FE, Peros WJ, Kent RL, Ago JM 1987 Synergistic interactions between interleukin 1, tumor necrosis factor, and lymphotoxin in bone resorption. J Immunol 138:1464-1468

43. Patton JS, Shepard HM, Wilking H, Lewis G, Aggarwal BB, Eessalu TE, Gavin LA, Grunfeld C 1986 Interferons and tumor necrosis factors have similar catabolic effects on 3T3 L1 cells. Proc Natl Acad Sci USA 83:8313-8317

44. Broudy VC, Harlan JM, Adamson JW 1987 Disparate effects of tumor necrosis factor- $\alpha$ cachectin and tumor necrosis factor- $\beta$ /lymphotoxin on hematopoietic growth factor production and neutrophil adhesion molecule expression by cultured human endothelial cells. J Immunol 138:4298-4302

45. Locksley RM, Heinzel FP, Shepard HM, Agosti J, Eessalu TE, Aggarwal BB Harlan JM 1987 Tumor necrosis factors $\alpha$ and $\beta$ differ in their capacities to generate interleukin 1 release from human endothelial cells. J Immunol 139:1891-1895 